\title{
Extent of Head Teachers' Utilization of Innovative Sources of Funding Primary Schools in Enugu State of Nigeria
}

\author{
Eze Thecla Amogechukwu' ${ }^{1}$ \\ Chidobi Roseline Unoma ${ }^{2}$ \\ ${ }^{2}$ Department of Educational Management, Enugu State University of Science and Technology, Enugu, Nigeria
}

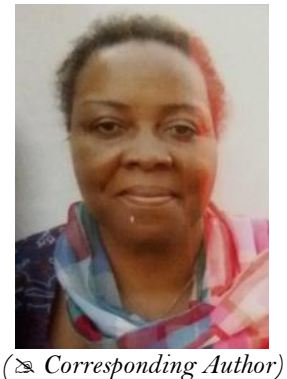

\begin{abstract}
The purpose of this study was to examine the extent Head teachers utilize innovative sources of funding primary schools in Enugu State of Nigeria. Descriptive survey design was employed to examine the extent head teachers utilize innovative sources of funding primary schools in Enugu State. Data were collected through a 14- item questionnaire titled; 'Extent of Utilization of Innovative Sources of Funding Primary Schools Questionnaire'(EUISFPSQ). A reliability coefficient of 0.79 was obtained using Cronbach Alpha method. The instrument was administered to 409 head teachers and teachers. A total of 400 copies were retrieved, 200 from head teachers and 200 from teachers. Mean and standard deviation were used to collate scores that answered the research question while z- score was used to test the null hypothesis at .05 level of significance. Findings of the study revealed that all the head teachers agreed to high extent that they utilized the funds from identified innovative sources of funding. Although some teachers disagreed but judging from the grand mean score of 2.61, teachers agreed to a high extent that head teachers utilized money generated from innovative sources in funding primary schools. Also there were no differences between the mean scores of head teachers and teachers on the utilization of innovative sources of fund in financing primary schools. Based on the above, it was recommended that in view of the economic recession, head teachers should articulate more innovative sources of generating funds for sustaining the primary schools and be ready to use the money in funding primary education.
\end{abstract}

Keywords: Innovative sources, Utilization, Funding, Primary schools and Extent.

Citation | Eze Thecla Amogechukwu; Chidobi Roseline Unoma (2017). Extent of Head Teachers' Utilization of Innovative Sources of Funding Primary Schools in Enugu State of Nigeria. Journal of Education and e-Learning Research, 4.(2): 41-45. History:

eceived: 20 March 2017

Revised: 1 June 2017

Accepted: 20 July 2017

Published: 17 August 2017

Licensed: This work is licensed under a Creative Commons

Attribution 3.0 License (cc)

Publisher:Asian Online Journal Publishing Group
Contribution/Acknowledgement: Both authors contributed to the conception and design of the study.

Funding: This study received no specific financial support.

Competing Interests: The authors declare that they have no conflict of interests.

Transparency: The authors confirm that the manuscript is an honest, accurate, and transparent account of the study was reported; that no vital features of the study have been omitted; and that any discrepancies from the study as planned have been explained.

Ethical: This study follows all ethical practices during writing

\section{Contents}

1. Introduction

2. Method.

3. Results

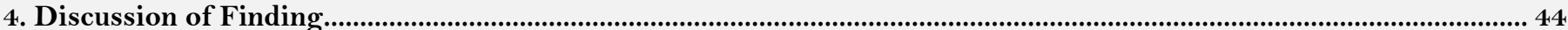

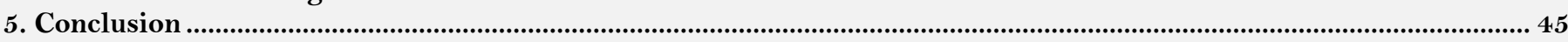

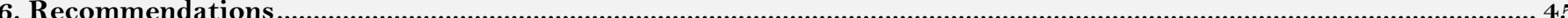

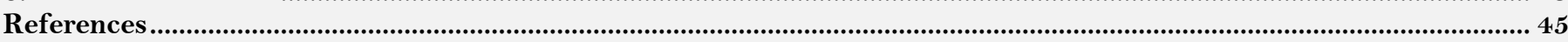




\section{Introduction}

The Federal Republic of Nigeria in her National policy on education Section 1, dealing with the philosophy and goals of education in Nigerian, states that Nigeria's philosophy of education is based on a set of beliefs which one of it is that education is an instrument of national development and social change.

Primary education is defined by Federal Republic of Nigeria (2013) as the first form basic education children receive before the secondary stage. Basic education is the foundation for sustainable life-long learning. It provides reading, writing and numeracy skills. It also comprises a wide variety of formal and non-formal educational activities and programmes designed to enable learners acquire functional literacy.

FRN (2013) the objectives of primary education are to:

a) Inculcate permanent literacy, numeracy and the ability to communicate effectively,

b) Lay a sound basis for scientific, critical and reflective thinking,

c) Promote patriotism, fairness, understanding, and national unity,

d) Instill social, moral norms and values in the child,

e) Develop in the child the ability to adapt to the changing environment, and

f) Provide opportunities for the child to develop life manipulative skills that will enable the child function effectively in the society within the limits of the child's capacity (pp21-22).

Going further, it states that in pursuance of these objectives:

a) Primary education shall be free, universal, compulsory, and qualitative;

Beautifully stated objectives, but in order to achieve these, current patterns of funding primary education may not yield the desired results.

\subsection{Concept of Educational Finance}

Finance is the science of management of funds. There has been a lot of debate about cost of education especially who should bear the cost of schooling. Otive (2006) reported that in a cost tracking workshop, organized by Action-aid from 10-13 October 2013 in Johannesburg, development practitioners drawn from Africa, Asia, Europe and Latin America discussed issues of education. At the end, participants allocated various costs of education to the government, community and the private sector. This group of people are known as stakeholders of education.

Although in Nigeria and Enugu state in particular financing of primary education through the payment of school fees is non-existent because fees are not charged since it is free and compulsory. This does not mean that their education is not financed. The stakeholders have some responsibilities to ensure that children are supported to acquire quality education. In view of the above, it was observed that education is not free anywhere in the world somebody, somewhere pays for it.

Ikediugwu (2007) opined that financing of education consists of provision of funds to establish educational institutions or sponsorship of individuals who pursue educational training. To this regard, the financing of education embraces all aspects of funding of education including the source of funding and how the money earmarked for education is spent.

The burden of financing primary education is shared among the local, state and federal governments as well as private sector and non-governmental organisations. However, the private sector, non-governmental organisations and faith based organisations fund their own primary schools.

Odekunle (2001) observed that the financing of Nigeria's education system has reached a crisis. Almost all the infrastructural facilities and learning materials are lacking in most public primary schools. This could be as a result of poor funding. In support, Aguba and Ani (2016) noted that Nigerian government has not been meeting the United Nations Educational Scientific and Culture Organization (UNESCO) recommendation of $26 \%$ of the total national budget allocation to the education sector.

As a means of remedying the financial predicament in Nigeria public primary schools, innovative financing is pertinent. Adedeji (2015) described innovative financing as a range of nontraditional mechanism to raise additional funds for development aid through innovative project such as micro contributions, taxes, public-private partnerships and market based financial transaction.

In the NPE's Strategic Plan for the development of the education sector 2011-2015, it is stated that as a turnaround strategy. This involves the federal government of Nigeria setting up a ministerial committee on exploring new and expanding existing opportunities to increase education funding.

This need is very crucial because of the vital role education plays both as a universal public good and public service. It is also an investment which increases productivity in its citizens as well as economic growth both of the individual and the nation.

Considering the current economic crisis, the need for innovative financing for primary education has arisen. Innovative financing according to International Expert Report (2012) represents stable and predictable flows that are complimentary to traditional Overseas Development Assistance (ODA). Bellinger and Fletcher (2014) asserts that aid to education is declining, and aid to basic education fell by $20 \%$ from 2009 to 2012. Furthermore, they stated that public spending on education is falling short, with only $25 \%$ of countries spending the recommended $6 \%$ of Gross National Product (GDP) to deliver quality education.

Burnett and Berminghan in Bellinger and Fletcher (2014) adduced five reasons that innovative financing is needed for education as follows:

- To reduce the financing gap and increase total resources for education.

- To raise the profile of education on global and national agendas.

- To improve effectiveness, efficiency and equity of education spending.

- To meet the needs of fragile states/especially conflict affected states.

- To promote innovation in education.

Durston (n.d.) on why we need innovative financing in education states that it is:

- To meet the Education for All Goals.

- To finance the gap (\$16 billion per year) with predictable and sustained funding. 
- To raise the profile and visibility of education.

- To encourage spending more effectively, with efficiency and equality.

- To address the needs of conflict-affected countries.

- To promote innovation in education programming and financing.

In furtherance of these reasons, we need to find innovative ways of financing primary education because of the unique position it occupies in the development of the individual educationally. The completion of quality primary school could have impact on economic growth, individual earnings, health, human security and the preservations of the environment. Nwachukwu (2014) makes a case for a proper funding of basic education over other levels not only due to limited availability of resources but to ensure a strong education base, so that products of secondary schools will be of such a high quality, that they would have acquired the knowledge and skills to participate actively in the economic and social process. In line with this, UNESCO in Domike and Edward (2014) states that primary education is the largest sub-sector of any education system and offers a unique opportunity to contribute to the transformation of societies through the education of young ones because it is found in every community both rural and urban, developed and developing economies.

\subsection{Strategies for Innovative Financing of Primary Education}

Innovative ways of financing primary education will definitely help in the sustainable development of any nation. The Global Monitoring Report shows that 250 million children are in school and not learning. This contributed to the shift from the Millennium Development Goal (MDGs) 2 and 3 to Sustainable Development Goal (SDGs) 4. This vulnerable group needs urgent attention from both planners and financiers.

Nwachukwu (2014) suggested options for funding education to include: regular contributions from communities, states, such levies on all adults to support schools, local government officials, churches, school authorities should be involved in the launching of appeal for funds.

Ige (2015) in suggesting strategies for sustainable financing of primary education in Nigeria states an introduction of compulsory education tax on public service workers in Nigeria. A minimal education levy of 100 for public servants, having at one time or the other benefited from education being provided by government. He also suggests that adults in a community where primary schools exist should be levied to help provide facilities for the school.

Mandatory dues, corporate social responsibility, Gender specific financing, 'pay for performance' based solution for SIB (social Impact Bond) a useful risk transfer mechanism is also advocated. Ekpo (2009) observed that every school system should have different innovative source of raising funds for the school. He is of the opinion that every institution of learning like primary should establish endowment funds where rich citizens assist in the development of quality education.

Ikediugwu (2007) asserted that launching of appeal fund cards have been an important area used for raising funds in secondary education. She added that the launching, if well utilized, will produce enough finances to help fund institutions. Adesina (2012) opined that old students of an institution are usually very proud to remember their Alma Mata, therefore this also be an alternative way of funding education.

Scholars of different categories have identified various innovative ways of funding primary schools. The discovery and the utilization of these will go a long way in solving the problem of finance that seems to be plaguing education and primary school in particular. Inadequate funding of primary education which has resulted in lack of infrastructural and material resources, low standard of teaching and learning, examination malpractices and other social vices, but the question is to what extent do the head teachers utilize these identified innovative sources of funding primary education.

\subsection{Purpose of the Study}

1. The major purpose of the study is to examine the extent innovative sources of funding primary education are utilized by the head teachers.

\subsection{Research Question}

The following research question guided the study.

1. To what extent do head teachers utilize innovative sources of funding primary education in Enugu education zone?

\subsection{Hypothesis}

The following null hypothesis guided the study and was tested at .05 level of significance

1. There is no significant difference in the mean rating of head teachers and teachers on the extent of utilization of innovative sources of funding primary schools in Enugu education zone.

\section{Method}

Description survey design was adopted for the study. The study was carried out in public primary schools in Enugu education zone. The population consist of all the head teachers and teachers in public primary schools in Enugu education zone (200) and 2092 teachers, totaling 2292 (Enugu State, 2014). Planning, Research and Statistic Unit). Proportionate random sampling technique was utilized to select $10 \%$ of the teachers (209). Therefore, the sample size for the study was $200+209=409$ respondents.

The instrument for data collection was a 14 item researchers' structured questionnaire titled: Extent of Utilization of Innovative Sources of Funding Primary Schools Questionnaire (EUISFPSQ). Two experts in Educational Management and one from Measurement and Evaluation validated the instrument. All corrections given were reflected in the final copy. To determine the reliability co-efficient of the instrument the reliability index was 0.79 which was obtained using Cronbach Alpha method. This was high enough for the study. The 
instrument was a modified 4-point scale ranging from Very High Extent (VHE) -4 points to Very Low Extent (VLE) - 1 point. This instrument was administered with the help of three research assistants.

Out of 409 copies of the questionnaire distributed 400 copies were retrieved, 200 head teachers and 200 head teachers) there by giving 400 return rate and $98 \%$. Mean $(\mathrm{x})$ and Standard deviation (SD) were used to collate scores that answered the research question while z-test was used to test the null hypothesis. For decision making, 2.50 was used as a benchmark, any item with a score of 2.50 and above was regarded as high extent while those scores less than 2.50 were low extent. For the hypothesis, if the z-calculated is greater than or equal to z-critical, the null hypothesis is rejected while if less the null hypothesis is not rejected.

\section{Results}

Table-1. Mean ratings of the respondents on the extent of utilization of innovative sources of funding primary schools

\begin{tabular}{|c|c|c|c|c|c|c|c|}
\hline $\mathbf{S} / \mathbf{N}$ & Items & $\overline{\mathbf{X}}$ & SD & Decision & $\overline{\mathbf{X}}$ & SD & Decision \\
\hline & $\begin{array}{l}\text { The extent of utilization of innovative } \\
\text { sources of funding primary school } \\
\text { through, }\end{array}$ & & & & & & \\
\hline 1. & $\begin{array}{l}\text { Regular contribution from communities, } \\
\text { such as levies }\end{array}$ & 2.66 & 1.07 & $\mathrm{HE}$ & 2.27 & 1.02 & $\mathrm{LE}$ \\
\hline 2. & Launching of appeals for funds cards & 2.63 & 0.72 & $\mathrm{HE}$ & 2.80 & 0.96 & $\mathrm{HE}$ \\
\hline 3 & introduction of compulsory education & 2.79 & 1.20 & $\mathrm{HE}$ & 3.57 & 0.85 & $\mathrm{HE}$ \\
\hline 4 & $\begin{array}{l}\text { minimal education levy of } \\
¥ 100 \text { for public servants }\end{array}$ & 3.09 & 1.09 & $\mathrm{HE}$ & 2.94 & 1.00 & $\mathrm{HE}$ \\
\hline 5 & $\begin{array}{l}\text { adult members of the community levied to } \\
\text { provide facilities }\end{array}$ & 2.82 & 1.12 & $\mathrm{HE}$ & 2.72 & 0.98 & $\mathrm{HE}$ \\
\hline 6 & $\begin{array}{l}\text { mandatory dues from corporate social } \\
\text { bodies }\end{array}$ & 2.35 & 0.98 & LE & 2.14 & 1.01 & $\mathrm{LE}$ \\
\hline 7 & $\begin{array}{l}\text { endowment fruits from rich citizens assist } \\
\text { in the development of quality education }\end{array}$ & 2.66 & 1.28 & $\mathrm{HE}$ & 2.98 & 0.82 & $\mathrm{HE}$ \\
\hline 8 & old students Association Alumni & 2.88 & 1.05 & $\mathrm{HE}$ & 2.87 & 1.05 & $\mathrm{HE}$ \\
\hline 9 & sales from farm produce & 2.82 & 0.90 & $\mathrm{HE}$ & 2.64 & 1.13 & $\mathrm{HE}$ \\
\hline 10 & sales from Arts and Crafts & 2.91 & 0.74 & $\mathrm{HE}$ & 2.72 & 1.09 & $\mathrm{HE}$ \\
\hline 11 & Renting of halls and classroom & 2.78 & 1.23 & $\mathrm{HE}$ & 2.72 & 1.18 & $\mathrm{HE}$ \\
\hline 12 & $\begin{array}{l}\text { Raffle draw by PTA to support fund } \\
\text { raising for projects }\end{array}$ & 2.68 & 1.00 & $\mathrm{HE}$ & 2.71 & 1.03 & $\mathrm{HE}$ \\
\hline 13 & Renting of football field & 2.71 & 1.03 & $\mathrm{HE}$ & 2.48 & 1.00 & $\mathrm{LE}$ \\
\hline \multirow[t]{2}{*}{14} & $\begin{array}{l}\text { The extent they utilized all fund for } \\
\text { primary school management }\end{array}$ & 3.08 & 0.93 & $\mathrm{HE}$ & 2.38 & 1.00 & $\mathrm{LE}$ \\
\hline & Grand Mean & 2.78 & 1.02 & HE & 2.61 & 0.94 & HE \\
\hline
\end{tabular}

Source: Raw scores analyzed by the researchers to get the mean and standard deviation.

Summary of result on Table 1 revealed that all the items including grand mean have means ranging from 2.3 to 3.09 for the head teachers' responses which means that all the head teachers except for item 6 agree to a high extent that they utilize the fund from the identified innovative sources of funding. This is because their means were above the benchmark of 2.50. Also, some of the items were responded to by the teachers as being utilized. they 2$5 \mathrm{~m}$ and 7-12, with grand mean. This shows that for those the teachers agreed to a high extent that the head teachers utilize them. Although for items 1, 6, 13, and 14 with means ranging from 2.14 to 2.48 , the teachers disagreed that those sources were utilized by the head teachers.

\subsection{Research Hypothesis}

Ho: The difference in the mean rating of head teachers and teachers on the extent of utilization of the innovative sources of funding in public primary schools

Table-2. Z-score statistical analysis on the response of head teachers and teachers on the extent of utilization of innovative sources of funding public primary schools, at .05 level of significance.

\begin{tabular}{l|l|l|l|l|l|l|l}
\hline Variable & N & Mean & SD & DF & Z-crit & Z-cal & Decision \\
\hline Head teacher & 200 & 2.78 & 1.02 & & & & \\
& & & & 398 & \pm 1.96 & 1.73 & Uphold \\
$\begin{array}{l}\text { Teacher } \\
\text { Total }\end{array}$ & 200 & 2.61 & 0.94 & & & & Ho $_{1}$ \\
\hline P S = NS not significant & $\mathbf{4 0 0}$ & & & & & & \\
\hline
\end{tabular}

Table 2 above revealed that calculated $\mathrm{z}$ value of 1.73 is less than $\mathrm{z}$-critical value of +1.96 at .05 level of significance and 398 degrees of freedom. Therefore, the null hypothesis is not rejected. This shows that there is no significant difference in the mean score of head teachers and teachers on the utilization of innovative source of funding public primary schools in Enugu educational zone, of Enugu, state.

\section{Discussion of Finding}

The result in Table 1 revealed that both the head teachers and teachers agreed to an extent that the head teachers utilize the innovative sources of fund raising in their schools. This is particularly necessary and encouraging because according to Bellinger and Fletcher (2014) there is a decline in the aid to education, more so that to basic education fell by $20 \%$ from 2009 to 2012 . Funds are very important for this level of education in the views of Domike and Edward (2014) considering the very important role that primary education plays in the transformation of societies through the education of its young ones as it is the largest subsection of any education 
system. Alternative sources of funding education is very necessary especially at this period of depressed economy. Ikediugwu (2007) gave an example of such alternative sources like the launching of appeal cards, of which if handled and organized properly will yield quite some amount to help fund schools.

The result of the study revealed that head teachers and teachers accept that the sale of students' handicrafts and farm produce raise fund for the school. This serves a dual purpose as pupils learn and also generate funds for their school. As also revealed from the study, funds are also raised through launching ceremonies and donations from benevolent business people from the community. This result is in consonance with the finding of Obidike (2014) who agreed that institutions often organize one form of launching and donation or the other.

Results from the study revealed that teachers and head teachers agreed that the identified innovative sources of funding are utilized by the head teachers in running the affairs of the school. The proviso attached to this is that a proper account of how such funds were expended must be given to the Enugu State Universal Education Board (ENSUBEB). If this is not done it could be tagged as illegal collection. Such activity will not only be stopped; the head teacher will also be sanctioned.

\section{Conclusion}

Based on the findings of this study which examined the utilization of innovative sources of funding public primary schools in Enugu educational zone, head teachers and teachers agreed that apart from the statutory government fund, the listed innovative sources of funding can also be used to generate funds for running the primary schools. Such funds as attested to by the head teachers and the teachers are actually utilized by the head teachers in the administration of the schools.

\section{Recommendations}

The following recommendations were made based on the findings of this study.

1. In view of dwindling economic resources globally, the time is ripe for head teachers to articulate more innovative ways of generating funds for the sustenance of primary education.

2. Government should give head teachers more latitude in raising funds as long as it is done within the stipulated financial regulations.

3. Head teaches and teachers should endeavor to always maintain good school community relationship as this could foster the interest of the citizens in donating money to the school.

4. An award should be instituted as an inspiration and recognition for best practices in the raising as well as utilization of innovative sources of funds for all levels of education, not just the primary alone.

\section{References}

Adedeji, O., 2015. Educational finance in Nigeria in Segun Adesina(ed) introduction to educational planning, Ife. University of Ife Press Ltd.

Adesina, S., 2012. Funding Nigerian universities. Faculty Lecture Series No.2. University of Ibadan.

Aguba, C.R. and A. Ani, 2016. Extent of utilization of innovative source funding strategies to increase internally generated revenue. A Paper Presented at the first Annual National Conference of the Department of Educational Management,Enugu State University of Science and Technology,(ESUT). 13-16 June, 2016.

Bellinger, A. and B. Fletcher, 2014. Non-traditional financing for education. EPS-PEAKS, DFID.

Domike, G.C. and O.O. Edward, 2014. An evaluation of the major implementation problems of primary school curriculum in Cross Rivers State. Nigeria. American Journal of Educational Research, 2(6): 397-401. View at Google Scholar | View at Publisher

Durston, S., n.d. Innovative financing for education. UNICEF.

Ekpo, E., 2009. Financing secondary education in declining resources in D.N.Nwachukwu (Ed). Contemporary Issues in Nigerian Education and Development.

Enugu State, 2014. Annual report statistics department. Enugu: Ministry of Education

Federal Republic of Nigeria, 2013. National policy on education. Abuja: Federal Republic of Nigeria.

Ige, A.M., 2015. Strategies to achieve a stable adequate and sustainable financing of primary education in Nigeria in this decade and beyond. Journal of Poverty, Investment and Development, 7: 55-60.

Ikediugwu, N.K., 2007. Educational finance and school business management. Enugu: Cheston Agency Ltd.

International Expert Report, 2012. Innovative financing for education: Moving forward education task force.

Nwachukwu, P.O., 2014. Funding education for sustainable development in Nigeria: Challenges and the way forward. Journal of Education and Practice, 5(20): 51-56.

Obidike, N.D., 2014. Administration and control of primary school education in Nigeria in Glad.O. Unachukwu and Perpetua. N. Okorji (Eds)., Educational Management: A Skill Building Approach. Rex Charles \& Patrick Ltd. Nimo. pp: 653-671.

Odekunle, J., 2001. Strategies for raising additional resources for education. Education Today, 10(1): 40-43.

Otive, 2006. Cost tracking report. Workshop Organized by Action Aid at Johannesburg. 10-13 October, 2013.

\section{Bibliography}

Ranayoy, B. and S. Reed, 2015. Innovative finance for education: AQ \& A with Ranayoy Basu, Reed Smith. Global Business Coalition for Education. 